MONITORUT, OFICIAL SI IMPRIMIERIILE STATOLOI IMPRIMERIA NATIONALX BUCURESTI - 1939 


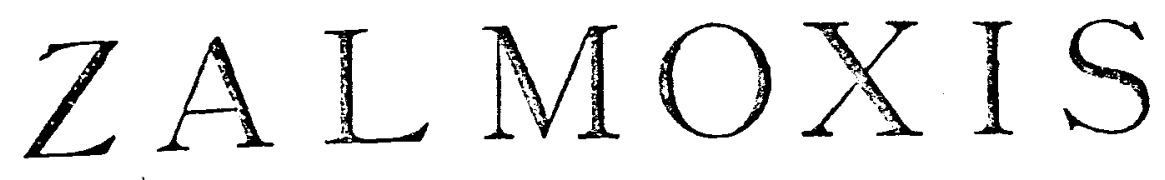

REVUE DES ÉTUDES RELIGIEUSES

\author{
PUBLIEE SOUS LA DIRECTION DE \\ MIRCEA ELIADE
}
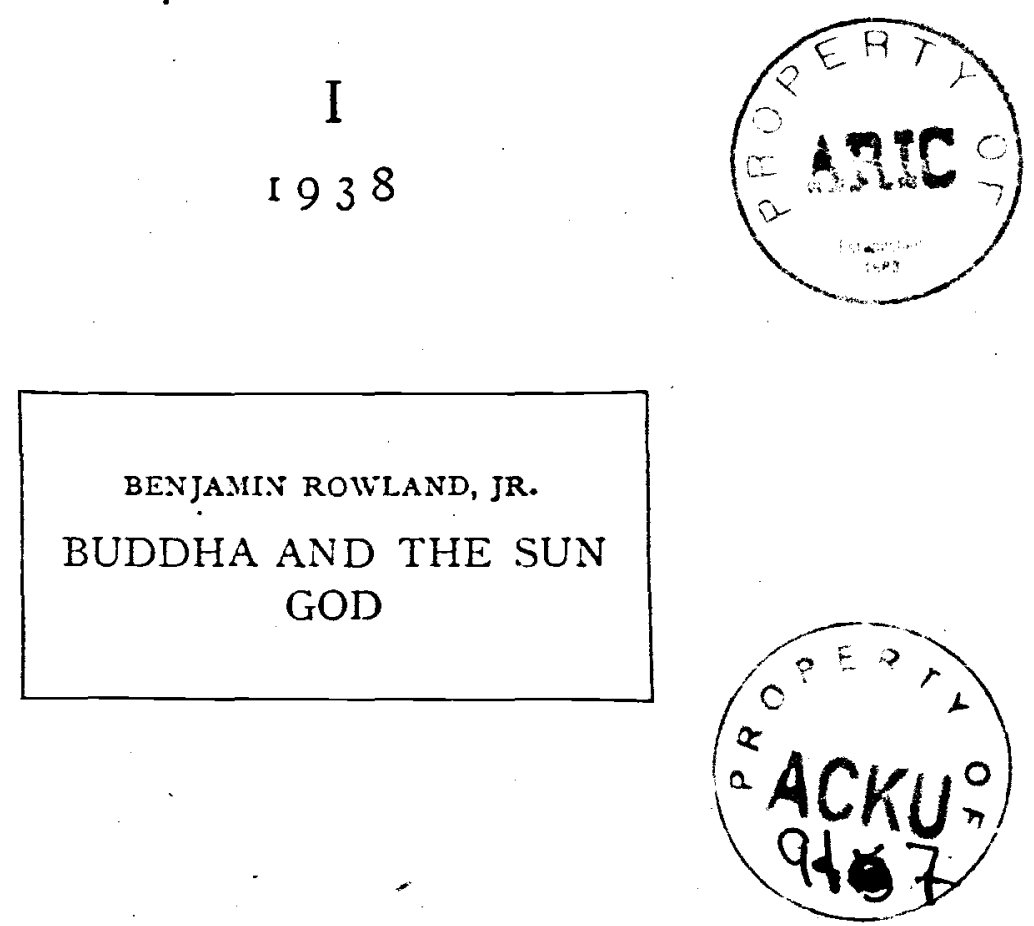

LIBRAIRIE ORIENTALISTE PAUL FIEUTHNER PARIS, 12, Rue Vavin, VI-e 



\section{BUDDHA AND THE SUN GOD}

One of the most striking pieces of decoration discovered by the French archaeological mission to Afghanistan is the vast painting that covers the vault over the head of the smaller of the two colossal Buddhas at Bāmiyann (fig. 1) ${ }^{1}$ ). It represents a personage in a long cloak standing in a four-horse chariot: he carrics a sceptre and has a sword attached to his belt; behind him is a light halo, its lower half filled by the drapery of the blue veil worn by the god over his mantle. The dark red nimbus is bordered on its rim by jagged a dog teeth or rays; inside its lower circumference is a thin crescent painted in yellow. The whole composition is framed in a bank of fiery red clouds and outlined against a background of deep ultramarine blue. Above the main figure appear female busts with scarves held spread over their heads, and flying gecse. Below the principal deity are two winged female figures with helmet, shield, and spear. When I visited Bāmiyann a year ago traces of the actual driver of the chariot standing on the pole were still visible. At the lower part of the composition, between wheels that resemble deep shields in profile, one can make out four winged horses: they are rearing and charging in two pairs on either side of the tongue of the car: the steeds are painted white with red outlines, and their small, leafshaped pinions are scarlet, too. As a whole the composition and the method of disposing its elements are not unlike the relief of the Sun God Sūrya at Bodh-Gayā (fig. 2).

As will be revealed in the pages that follow, it.is my opinion that this composition combines iconographic and stylistic elements that

') Hackin, J., Godard, Y, and A., Les Antiquitis bouddhiques de Bämigan, Pari:., 1928, pl. XXIl and fig. 6, p. 12, and Rowland, B., The W'all-paintings of Iriia, Central Asia, and Ceylon, Boston, 1938 , pl. 6. The present article re* prescnts a revision of suggestions 1 put forward on pp. 57-60 of the latter work. 
one would expect in a region where religions, languages, and various national artistic styles met to produce the curiously syncretic faith and art that we associate with the rule of the Kushans and their successors in this borderland between Iran and India. This is the later phase of a syncretism that began with the introduction of a whole pantheon of western, perhaps Sabaean, deities into the Kingdom of the Kushāna; at that time, as they are seen on Kanișka's coins, they may simply represent old Scythic shamanist gods who have been given new names and typified ${ }^{1}$ ). Specifically, I am inclined to regard this wall-painting as an absorption into Buddhism of the one of the solar deities whose cult flourished both in Iran and Vedic Incia under a variety of names, for, although the main decoration of the soffit of the niche has been identified as a moon god, this attribution has never seemed to me appropriate or possible from an iconographical point of view ${ }^{2}$ ). There is no particularly good reason for the juxtaposition of a lunar divinity with the eight Buddhas painted around the haunch of the vault, nor does any literary source known to me explain the significance of such a moon god - Candra, Mah, or Mao - in relation to the great statue of Salkymuni - that is, unless one wishes to attribute to this heavenly quadrig a merely astronomical space symbolism - an indication of the firmament over the head of the image ${ }^{3}$ ). The iconography of the god in a quadriga with his two brides and a charioteer corresponds exactly to many representations of the sun gods: Sürya, Helios, Mithra ").

Certainly even in the primitive phase of Buddhism, Sàkyamuni came to be identified with the sun god or the Vedic divinities of light the A'dityas - "that he had been thought of very early as

1) For finds of Kushan coins at Charax, sce Hill, G. F., Catalogue of Greek Coins of Arabia, Mesopotamia, Persia, London (British Museum), 1922, pp. CXV-CXCVI. Nanaia, who appears frequently on the Kushan coins was the great goddess of Elymaia (Kennedy, J., The Secret of Kanishka, FRAS, r912, 2. Pp. $1005-\cdot 1006)$.

2) In the first place, the chariot of the moon was drawn by oxen (Cf. Saxl, F., Frühes Christentum und spätes Heidentum in ihlen kïnstlerischen Ausdrucksformen, Wiener Jahrbuch für Kutistwissenschaft, 11, 1922-23, p. I12), whereas the sun god goes up the sky in a quadriga of white horses.

2) Excert in the sense that Buddha as . Sun - supports the sky.

1) Ie la Vallee-Poussin refers to this painting as le Bouddha en dieu de Soleil (Dymasties et Ilistoire de l'Inde depuis Kanishka jusqu'aux ine sions musulmanes, Faris, 1935, P. 353, n. 1). (f. Herzfeld, F., Dic sasanidischen Quadrigae Solis ot Lurac, Archäologische Mittrilungen ons Iran, 1930, P. I31. 
"a descendant of the sun' or aspect of Agni ${ }^{\prime 2}$ ). It may be that a contributing factor was some such concept as the Vedic idea of the sun as the eye of Yaruna that sees all: this, according to Dr. Coomarasivamy is to be taken as the explanation of the relief of Sürya in his chariot at Bodh-Gayāa ${ }^{2}$ ).

The reliefs in the porch of the vihära at Bhajaj present another case where Sürya stands for the Buddha: these two reliefs of Sūrya and Indra together constitute a symbol of Buddha's reflection of cosmic forces. In the ancient Indian cosmological system we must imagine the trinity of the Sun, Indra-Vày, and Agni as making up the axis that pillars apart the empyrean and the infra-cosmic waters ${ }^{3}$ ): Agni, as the smoky or fiery pillar may be said to hold up the sky: Buddha as the fiery pillar would appear to be Agni or an incarnation of Agni '). The Bodhisattva Siddhārtha takes his seat on the altar where Agni, kindled as the sacrifical fire, rises to heaven as the Sun (Sürya) ${ }^{5}$ ). The equation of Buddha to Agni (Fire) or Sürya (Sun) is the same in any case. Of the two possibilities open to him in this final avatar - represented in the Vedic dual Indrāgni, those of Great King or Priest - Buddha, in choosing the latter, chooses the part of Agni (Sürya) in the main ${ }^{6}$ ). In the $R g$ Veda, Agni chooses Indra for himself; and so, in Buddhism, Indra, whom we find in constant relation and cooperation with Agni-Surrya (Buddha), is associated with him as protector (the function of the temporal power) ${ }^{7}$ ).

This question of Buddha's connection with earlier solar cults was broached originally by Émile Senart who, indeed, reduced the whole mortal life of Sākyamuni to an ailegory of a sun

1) Coomarasuramy; A. K., La sculpture de Bodh Gayd, Ars Asiatica, Paris, 1935, P. 24.

2) Ibid., f. 44, n. 2. Cf. Buddha as the - Eye of the World ' and his identity with Mitra in Coomaraswamy, A. K., Elements of Buddhist Iconography, pp, $24-25$.

2) Satapatha Brāhmana, III, I1, 3, I.

4) Coomaraswamy, A. K., Buddhist Iconography, p. so and n. 84 (p. 65).

b) $S B E, 4^{6:}$ Mandala V, 6, 4, etc.

b) Coomaraswamy, (p. 42, n. 97), p. 81.

7) Indra is constantly associated with Buddha: he brings the straw on which the Bodhisattva takes his seat beneath the bodhi tree. This corresponds to the spreading of the sacrificial straw for Agni on the altar (Satapatha Brdhmana III, 8, 6, 18, $1 ;$ RV, XV, 9, $x$ ). Agni descends to sit upon the stra w' on his altar; from the Fire on the altar rises the fiery column to become the Sun in Heaven. Buddha sits on the grass beneath the tree and rises, Enlightened, to shine, illuminate. 
myth ${ }^{1}$ ). Without going as far as this, it does appear certain that there is in the Buddha legend an inheritance from the belief in the Cakravartin and his function of turning the solar wheel ${ }^{2}$ ). For the purposes of the present iconographical study it will not be necessary to enter at length into this and the question of the indentification of Time and the Sun and the Wheel: the whole question has been brilliantly discussed by Dr. Coomaraswamy in his Elements of Buddhist Iconography and further by Mr. Mus in connection with the cosmological significance of the Särnāth column ${ }^{3}$ ). Suffice it to say that the Wheel which the Cakravartin turns as governor of the cosmos and which becomes the symbol of Buddha's preaching, is at once symbolic of the revolution of the solar disc and, since the sun measures our days, of Time. It must be thought of, too, as the Wheel of the solar chariot, the vehicle of a ruler, the wheels of which roll everywhere without obstruction. Of extreme importance to us in relation to the Bāmiyan fresco is a penetrating statement by Dr. Coomaraswamy that links the elements of the concept of Cakravartin as Turner of the Wheel with the later identification of this symbol with the solar chariot which is an aspect of the revolving sun wheel: "No distinction of meaning can be drawn between the driver of the solar chariot and him who makes the solar wheel revolve" 4 ). One of the epithets applied to Buddha is Rajā Cakavatti, "Sovereign Mover of the Wheel ". Sakyamuni, in turning the "Wheel of the Law (Dharmacakra)", assumes the function of "Wheel King *
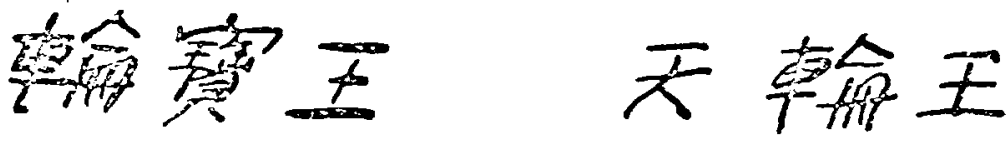

(Jap., Rinbō-ō

or Tenrinō)

and himself becomes the cosmic charioteer ${ }^{5}$ ).

1) Senart, E., Fssiai sur la legende du Bouddha, Paris, 1875, Pp.504-507. - The historical narrative of Buddha's life... must be regarded as a contraction or reflection of the cosmic relations ". (Coomaraswamy, p. 65, n. 14).

2) Dr. Coomaraswamy has kindly pointed out to me a Pre-Buddhist reference to the Saptaratna in the Brhaddevata, V, 23 and RV, VI, 74, 1 .

-) Coomaraswamy, A. K., Buddhist Iconography; fp. 24-33; Mus, P., Barabudur, I, Hanoi, 1935, p. $8_{4}, 150$ ff., etc.

-) Coomaraswamy, p. 28 .

8) Sec Grassmann, W'ortcrbuch zum Rigeeda, Cakra (2) ' yom Rade der Sonne.. gewöhnlich mit praqrti (vorkărtsbewegen) gebunden.. 
It would be impossible to give in detail all of the references to Buddha as a solar divinity: it will suffice to quote those that seem to have a bearing on our subject.

Sutta Nipata (SBE, X, 2), p. 69: "They (the family of Gautama). are Adiccas (ādityas, "Suns") by family, Sākiyas by birth \#; p. 93: "...true kinsmen of the Adiccas .

Again, in the Mahä-Sudassana Sutta (SBE, XI, pp. 244-245, 252) Buddha is identified with the Cakravartin, the \& Great King of Glo:y ", who rolls the sun wheel across to skies.

Significant as at least partly explaining the mentality that led to the eventual emergence of the Biddha and Sun myths is a passage from the Buddhacarita in which Sakyamuni, on entering the "place of austerities ", is mistaken for the Sun god or the Moon: "This is Sūryadeva or Candradeva, coming down * (SBE, XIX, 72).

This is enough to show that fundamentally the identification of Buddha with the sun seems to have grown up within the complex of Indian philosophic-religious ideas. The transformation of the Buddha into the driver of the solar chariot is not markedly different from the ideology that deified the Roman Emperor as Helios-Kosmokrator and Khosrau as the brother of the Sun and Moon: as an example of this iconography we may cite the portrayal of Caracalla and other rulers as the sun god Helios ${ }^{1}$ ). Something of the same concept is seen in the Early Christian representations of IIelios in connection with figures of Peter, the Good Shepherd, etc.; Philo of Alexandria saw the Logos in the rising sun; in the poetry and exegesis of Christian Egypt, the morning orb is Christ himself ${ }^{2}$ ). In the tympana of the cathedrals of Parma and Piacenza (fig. 3), the Sun is included as a symbol of Christ as the Light of the World; the Moon, the reflecter of this light, as a symbol of the (hurch ').

1) Biendel, O., Das Schild des Achillcs, Die Antike, XII, 4, 1936, p. 272 ff. The Emperor Galerius as "Kosmokratur ' is represented seated above the sun and moon on his triumphal arch at Saloniki (Cf. Peirce, I1., and Tyler, R., L'art byzantin, I, Paris, 1931, pl. I). For the idea of the Kosmokrator in Iran, see Saxl, pp. 106-107, I10-112.

2) Fiiger, W., Zur Entstchung und frühen Entti-llung der altchrisllichon Bildkunst, Studien über christliche Denkmäler, 23. Leipzig, 1929, p. 249. For an Eatly Christian representation of Helios, sce Wilpert, J., I sarcofagi cristiani antichi, I. Rome, 1229, Tav. I, 3 (Sarcophagus from La Goyelle).

2) Porter, A. K., Lombard Arclitecture, I, New lliven, 1917, p. 352. It may be noicd that there is at Kirisch a vault decoration representing, not only the 
Various elements in the Bāmiyan painting to be examined later show it to be just such a combination of classic and Mithraic ideas.

It may seem difficult to reconcile the presence of the "lunar" crescent in the circle of the nimbus with the representation of a sun god. Such combinations do exist, however, as on a relief of Sūrya at Māñcapuri ${ }^{1}$ ). It was already an established iconographic custom to place the sun and moon god on either side of distinguished personages ${ }^{2}$ ): on the relic casket of Kanișka, the king is attended by Mihira (Mithra) and Mao ${ }^{3}$ ); they appear together on a coin of Huvișka ${ }^{4}$ ). Their costumes, attributes, etc. combined would present a figure exactly like the divinity at Bāmiyān. It may not be too subtle to read into this combination something of the idea embodied in the Saddharmapundarika in which Prabhūtaratna's and Buddha's meeting in the stūpa may be regarded as the sun and moon in an asterism: that is, Prabhütaratna is the moon at the time of amãa äsyä, in conjunction with the sun ${ }^{5}$ ). We may perhaps compare the growth of this inconographical concept at Bāmiyàn to the Roman myth of Attis as the shepherd of the stars, as Adonis, Mithra, etc.: a * poly-

chariots of the sun and moon, but also winds, constellations, and Buddhas flying in the Zenith. The meaning of this Buddhist planetarium is puzzling: it might be intended simply like a Baroque ceiling painting to suggest the open sky with its stars and planets, but, as in all oriental religious art, we must look for a deeper significance. Probably this Central Asian painting refers to the Buddhas as ruIers of the heavenly bodies and has reference to the passage of Time through their movements; possibly it may have something to do with the gathering of celestial hosts, including the Sun god and the Moon god, at the preaching of the Saddharmapuṇarlka. (von Le Coq, A., Bilderatlas zur Kunst- und Kulturgeschichte Mittelasiens, Berlin, 1928, fig. 220).

1) Coomaraswamy, p. 44. Another relief of Surya from Mandor seems to have the srescent in the halo (cf. ASI, AR, 1909-10, pl. XIIII, 6).

') In the same way the Sun and Moon as ministers, of Christ survive in mediaeval iconography - notably on the Cathedral of Piacenza, cf. Porter A. K., Lombard Architecture. New Haven, 1917, I, p. 350, and, at Parma, pl. 165, p. 4; pl. 164, 2. At Parma we have the Sun god (Helios) in a chariot and Selene in a biga. It is nutable that above this lower representation, Helios, with rayed halo, is shown in a crescent as is the corresponding bust of the moon.

-) Bachhofer, L., Early Indian Sculpture, II, New-York, 1929, pl. 148.

4) Gardner, P., Greck and Scythic kings of Bactria and India, Catalogue of Indian coins in the British Museum, III, London, 1886, pl. XXVII, 24 and p. 141 de la Vallée-Poussin mentions the continuation of this customs to the present day, (op. cit., 353, n, 1).

') Kern, H., The Saddharma Pundarika, SBE, XXI, p. 230, n. 1. 
morph" or "pantheon "having the solar corona and the lunar crescent at one and the same time ${ }^{1}$ ). 'The central figure of the Bämiyan fresco is dressed like Mithra on the coins of Kaniṣka and Huvişa; like these representations he is armed with sceptre and sword ${ }^{2}$ ). In Babylonian mythology the Sun is the male principal or Heaven, the Moon the female or Earth: combinations of crescent and disc on the Babylonian seals symbolize then the marriage of principals parted at creation. "At the end of the sky there Heaven and Earth embrace (JUB, I, 2. 2, I. 2. 5) ". They are joined by the cosmic axis; the union symbolizes the fruition of the Buddha's cosmic activity "). ",

Parallel to the spiritual forces that identified Buddha with Sürya is the metamorphosis of Mithra into Maitreya: an examination of this syncretic process will be of value to us in explaining the definitely Mithraic character of the Bāmiyān wall painting. Sylvain Léri has called attention to the confusion of Maitreya with the sun in the Mahäbhärata: he is alluded to as karunänvita "the merciful. - an epithet reserved for the sun; again, he is referred to as " good to friends (mitra) "4). The Mahäbharata further calls the sun Maitreya and, again, Mihira or Mitra s). The name of Maitreya's co-disciple, the obscure Ajita, meaning "invincible *, is given to Maitreya as a first name; the combination strongly suggests the title "Mithra Invictus". In his well-known capacity as Messiah, Maitreya is the Buddhist equivalent of the Mithraic Saoshyant ${ }^{6}$ ). Przyluski, working independently, has come to the same conclusions: he takes Maitreya to be a derivative or cognate of Mithra ?). In the

1) Cumont, F., Textes et monuments figurés relatifs aux mysticres de Mithra Paris, : 896 , p. 66.

2) Gardner, XXVI, 10; XXVIII, 1, 2, 4.

3) In Tibetan Buddhism such combinations of the solar disc and the lunar crescent symbolize the reabsorption of the soul into the supreme reality. The two devices are the two coefficients from which springs the fire of supreme illumination (bodhicitla). These same meanings are attached to the so-called zla-fii ornaments which are worn as talismen. Sce Tucci, G., Indo-Tibetica, I, Rome, 2932 , pp. $47-48$ and pl. XLIII.

-) Lévi, S., Maitrez'a le Consolateur, Mélanges d Orientalisme drdiés d la memoirc de $R$. Linossicr, II, Paris, 1932, p. 359.

5) de la Vallée-Poussin, p. 353.

c) Ibid., p. 352 .

') Przyluski, J., Un Dieu iranién dans I'Inde, Rocznik Opjentalistyczny, VII, 1930, pp. $1-9$. 
Rgveda, Mitra is either the Sun or Agni and thereby in Buddhism equivalent to Buddha; again Maitreya, the spiritual son of Buddha, is etymologically the "Son of Mitra". In either case the equation of Buddha to Mitra remains the same. Whether the iconography of the painting at Bāmiyan is derived from the Vedic Mitra or has elements taken from his later aspect as the Sasanian Mithra can only be decided in the analyses of some of the details of the composition.

Mithra as a sun god appears on a Sasanian seal in the Kaiser Friedrich Museum in Berlin ${ }^{1}$ ): the cameo is inscribed Mumitre e Parsum, "Mithra the Good, the son of Parsuma "; the bust of the divinity in a rayed halo appears riding in a chariot drawn by two winged steeds (fig. 4). The analogy of the main elements of the composition to the Bāmiyān paintings is triking ${ }^{2}$ ), so striking that we might regard it as proof of the Iranian origin of the whole conception.

What might seem to be the final piece of evidence to establish the Mithra-Maitreya-Buddha cognate comes in a piece of Gandhāra sculpture that has long been known and was originally published by Foucher as "Char du Soleil" (fig. 5). It is again iconographically close to the Sasanian and Afghan examples. Seated on a throne fixed on the four-horse chariot is a personage wearing the dhoti and jewels of the Gandhāra Bodhisattva; the right leg is crossed over so that the foot rests on the opposite knee ${ }^{3}$ ). Two female figures stand to right and left. A halo with an engraved crescent within it appears behind the head of the central figure. It was on account of this crescent - which as we have seen is joined or "married" to the sun - that Herzfeld referred to the same relief as the Moon god ${ }^{4}$ ). In pose, the figure in the vehicle - totally un-

1) Herzfeld, E., Der Thron des Khosro, Fahrb. der kōnigl, prcuss. Kunstsamml., 1920, p. 108, Abb. 14; Herzfeld has also published a sort of companion piece to this seal with the moon goddess framed in a crescent and driving an ox-drawn biga - Die sasanadischen Quadrigae solis et Lunne", Archäologische Mittcilungen aus Iran, 1930, Taf. 1 .

2) The use of the halo with saw-tooth border or with rays here at Bamiyan, in Gandhāra, and Mathurā statues may be a corollary of the solar cult of Buddha since this type of nimbus was traditionally associated with Helios and Mithra.

') Foucher, A., L'art gréco-bouddhioue du Gandhära, I, Paris, 1905, fig. 83, p. 207 .

4) Herzfeld, E., Der Thron des Khosro, Jahrb. der königl. preuss. Kunstsanmlungen, 41, 1920, p. 108. In . Die sasanidischen Quadrigae", he refers to the Bãn:iyān fresco as a 1 sun god. 
like any known version of Sūrya - is the prototype of that unearthly figure in revery at Chügüji in Nara: the type that temple tradition in the Far East calls Sākyamuni or the Bodhisattra Maitrcya "): Budcha, Phœbus-like, has taken his place in the chariot of the Sun. Since the quadriga at Bämiyan was painted in connection with the colossal statue of Sākyamuni it is probable, however, that Buddha himself in his solar aspect is intended and not, as the "Mithraic. character of the composition might cause one to believe, Maitreya. It may be that the Mithraic features of the picture are due to such a confusion of the Buddha-Maitreya iconography but, as will be demonstrated below, it is very likely the birth of Gautama that is referred to in this fresco of a Sun god. Finally, a reference in a Central Asian sūtra confirms us in the belief that Buddha Sākyamuni is intended, since there Buddha is definitely thought of in connection with a "sun chariot". "A noble youth, or a noble maiden abides for the space of six weeks, with well-purified mind, in the forest, in the mental vision of realized Buddhahood. Thus by his meditation on the sun-chariot (Sūrya yāna or Sūrya vimāna) of Budiha, by its rays, with respect to all (four) departments of this mind, the (two) elements, and the (two) spheres of sense, his growtl in charity, temperance, self-restraint, the six perfections (and so forth on down) reaches fullness... ${ }^{2}$ ). Also the concept of Sākyamuni as Sun-god had been used as a motif in art as early as the Bodh-Gaya relief of Sūrya.

We have yet to establish the connection between the cciling painting of the sun chariot and the figures of cight Buddhas which are painted on the sides and back of the niche, directly adjoining the ceiling decoration. The explanation of this relationship as well as renewed corroboration for identifying the vault fresco as a synibol of Buddha is found in a relief from Mathura on which we find a carving of a series of seenes from the life of Buddha with Sürya

1) Wegner, F., Die Ikonographie des Chinesischen Maitreya, Ontasiatische Zeitschrift, NF. 5, 1929, 5, p. 217. No single inscribed statue of Maitreya of this type is known. Traditionally, however, images in this msture of reyerip are called Nyoirin Kwannon or Miroku (Maitreya) in Japan. At Yün-Ka\&. however, there are a number of representations of Salyamuni in this gese. (Cf. Sirén, O., History of Chinese Sculpture, vol. 11, London, 1925, pl. 24) n

2) Hoernle, A. F. B. Rudolph, Mamuscript remains of Buddhist found in Eastern Turkestan, vol. 1, Oxfurd, 1916, Pp. 99-100.

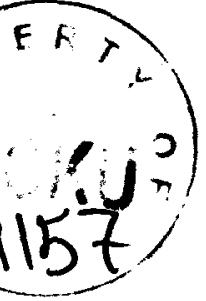


occupying the panel that would normally be allotted to the Birth of Buddha - combined, in a lower register, with representations of the Seven Buddhas of the Past and Maitreya, the Messiah (fig. 6) ${ }^{1}$ ). The literary source justifying the substitution of Sürya the Sun for Buddha's Nativity may be found in the passages on Sākyamuni's birth in the Buddhacarita, all of which emphasize his solar character: $(I, 28)$ "Like the sun bursting from a cloud in the morning, ... so he too, when he was born from his mother's womb, made the world bright like gold, dispelled the darkness;

$(I, 3 \mathrm{I})$ " He shone like the young sun descending upon the earth ;

$\left(I, 3^{2}\right)$ a. . . by the radiant splendor of his limbs he extinguished like the sun the splendor of the lamps :;

$(I, 74)$ "He will shine forth a sun of knowledge to destroy the darkness of illusion in the world $\mathbf{2}^{2}$ );

(I, I I) "Gradually emerging from the womb, he shed in every direction the rays of his glory ";

$(I, 13)$ "Perfectly adorned, sparkling with light, he came from the womb as when the sun first rises ${ }^{3}$ ).

Looking at it in an only slightly different way, this composition, like the one at Bodh-Gayā, might be taken as a symbol of Buddha's birth on the "altar - that is, Buddha's true or eternal birth into the worlds in the Mahāsambodhi - the equivalent of Agni's kindling to rise as the Sun ${ }^{4}$ ). Probably we would be right in assigning the same symbolism to the Gandhāra relief of fig. 5 .

This juxtaposition of elements in the Mathura frieze is exactly the same scheme of relationship that we find here between the god of the vault and the eight Buddhas portrayed on either side of the niche. The symbolism is an obvious one: we have the Buddhas of the Past and the Future Buddha, Maitreya, on the haunch of the vault; the Sun chariot on the soffit is the radiant birth of Sakyamuni.

1) Vogel, J. Ph., The Mathura school of sculpture, ASI AR, 1909-10, pl. XXV-a and pp. $69-70$.

2) Buddha Karita Sütra, SBE, XLIX, ı.

') Fo-Sho-Hing-Fing (Chinese version of the Buddhacarita of 408 A. D.) $S B E, \mathrm{XIX}$.

6) Sénart, E., La Légende du Bouddha, Paris, i 875, p. 425: (le) trone du Bouddha substitue ì l'ancien autel brahmanique "; (le Bouddha) perpétue sous une forme nouvelle in présence du feu sacré.. 
who illumined the world in this age; below, the great statue represents the fully enlightened Buddha. In this connection, I raise thequestior. whether the enframement of red "clouds * in the Bāmiyān fresco that stands for Sākyamuni's Nativity may not really be a cognate of the rocky borders of the Mithraic reliefs: this appears as. especially significant since the rugged frames of the Mithra reliefs. refer not only to that god's hidden activity in caves but also to his. manifested birth from a rock ${ }^{1}$ ). The whole scheme at Bāmiyann thereby becomes understandable and is conceived directly in connection. with the sculptured colossus of Buddha ${ }^{2}$ ).

It might be adduced further that the colossus of the Buddha is conceived as the axis of the cosmos, or the Cosmic Man, a supporting the sun above. The whole niche, then, could be thought of as. the atmospheric envelope of our world; just as the hemispherical dome of the stuppa is a replica of the "bowl of the sky ${ }^{3}$ ).

In connection with this problem, I mention a Bodhisattva in a dealer's hands which has a headdress with a Buddha in an elaboratetoothed halo seated in a quadriga; this four-in-hand stands on an. enframing crescent (fig. 7). Are we to understand this as another representation of Sākyamuni as Bodhisattva with the Buddha-Sūrya or Ajita-Maitreya (Mithra-Invictus) as an attribute? Something of the sort is certainly intended. It is difficult to decide in this latter

1) Cf. Cumont, p. 178. Both may come from the idea of the birth of Shamash from rocks; ef. Roes, A., Greek Geometric Art., London, 2933, Pp. 95-96.

2) In relation to the possible origin of this later iconography of the BuddhaSun concept we should not forget, although it has only an indirect bearing on the present problem, the identity of Amitabha with the Iranian deities of Light. His Paradise is in the west: " on l'apercoit en contemplant le soleil couchant ." Vogel, J. P. H., p. 353 .

Amitābha's spritual son, Avalokitestara, has a lunar character assigned to him in the title Sasankardhadharammardhni, t bearing a crescent upon his brow 2 Very possibly, then the moon, too, may be a symbol of Amitabha since he, as Dhyani Buddha, usually sits on Avalokitesiata's brow. This may explain the crescents appearing above the reliefs identified as . The Great Miracle " but more likely primitive portrayals of Sukhäsatl. (Cf. $A S I, A R, 1907-08$, p. 144, and pl. XLIV, c.). A marble head of a Bodhisattva from Gardez in the muscum at Kabul has a figure in a crescent on its turban. Likewise, the cult of Avalokiteśara has sometimes been regarded as a derivation from the sun-worship of the Sauras and Magi: Padmapani is a title given both to Avalokitesvara and Sorya.

') Cf. Mus, pp. Ios ff. 
case since this statue may be, as Dr. Coomaraswamy once suggested in discussing the Gandhāra Bodhisattva, the portrait of a Kushan Rajah as a Bodhisattva with Buddha as sun god in his turban ${ }^{1}$ ). In either case the equation of the Buddha with the sun is evident. Returning to the question of the possible Western or "SasanianMithraic "character of the work, it is undeniable that certain aspects -of the conception of the vault painting at Bämiyān are of purely western origin. These curious figures, half bird, half human, that flutter at the side of the advancing chariot, are immediately explainable as slightly orientalized concepts of sirens who appear in Indian art as Garudas or Kinnaras. I regard these as actual "Sirens " whose appropriateness in this planetary composition is apparent, since in antique astronomical iconography, the sirens are the deities that control the music of the spheres: as such they are seen in the dome of the adyton of the Bel temple at Palmyra with a diagrammatic symbolic map of the heavens and the planets (fig. 8) ${ }^{2}$ ). The memory of this connection with the heavenly bodies explains their place in the sun-god's train at Bämiyãn.

At the top of the picture are two truncated busts of women represented as though flying with scarves billowing above their heads ${ }^{3}$ ). These are apparently symbols of two of the four winds; they might possibly be in accordance to the ancient belief that the wind rises

1) Coomaraswamy, A. K., The origin of the Buddha Image, Art Bulletin, IX 1927 , P. 309.

3) Curtius, L., Musik der Sphären, Deutsches archäologisches Institut. Mitteilungen, Romische Abteilung, 50, 1935, p. 348-353. This iconography is based, on the description in Plato's Politeia, 10, 115,616 A ff. Cf. Adam, J., The republic of Plato, 2, 439 f. The idea is borrowed by Boethius (De Musica Patrol., LXIII, col. 1171); Cf. Mâle, E., L'art religieux du XII-ème siècle en France, Paris; 1924, p. 316. Later, in the Middle Ages, the conception arcse, That the spheres of heaven, each of which contained one planet, were revolved by angels (Porter, III, D. 253, n. 36) - a Christian survival of the Siren myth. This new twist of the iconography is represented on the central portal of Piacenza cathedral. Cf. Cosmas Indikopleustes, Topografia Cristiana (Ed., McCrindle, p. 323), 310: - The angels move the luminaries and the stars and all else *.

2) Although it may be difficult to think of these winds as female - since Vayu is a male god - from the fact that the words for quarter dis or disá or pradif are all feminine (in $A V .11,10,4$, they are said to have taken the Gale for their Lord; i. e. husband, as expressed by the word vatapatnih), one might argue that the four winds might be regarded as feminine in relation to the Wind, mascul ine. 
at sunrise and sunset. In late antique art they are frequently placed near Helios and Selene in pairs of two or four ${ }^{1}$ ). It must be remembered that figures with scarves of this type are sometimes held to represent Nyx or Night - as for example on the planctary shield of Achilles on the medal of Caracalla in Berlin ${ }^{2}$ ). A wind god (OA $\triangle O$ ) with fluttering scarves occurs on a coin of Kaniska ${ }^{3}$ ). The geese at the very top of the composition are presumably the Hamsa of Indian mythology "). Turning to the lower part of the fresco, the horses are represented as in Western portrayals of Helios as four separate beasts - the inner pair slightly overlapping the wheel pair. By a sort of geometric projection, the outer pair disappears, and we have only two horses seen in profile on either side of the tongue of the chariot as in the Surrya of Khair Khana and the sun gods painted at Kizil and, further east, at Tun-huang ${ }^{5}$ ): the elements of the composition are purposely disassociated so as to be seen from the most typical - the profile - point of view ${ }^{\circ}$ ). This typical oriental mental concept was evolved independently and is in no case to be taken as a "conventionalization" of an earlier enaturalistic" form.

1) They are the Aurae velificantes sua veste of Pliny (36, 29). The 'Winds * as depicted at $B$ āmiyan are duplicated in a ceiling decoration of the zenith at Kirish (von Le Coq, A., Bilderatlas zur Kunst-und Kulturgeschichte Mittclasiens Berlin, 1925, fig. 220). Genii of Air and Water appcar on the Ara Pacis as women riding on swans; they hold flying scarves over their heads - recalling Pliny's description. It may be that the reduction to mere busts took place in Coptic art: Cf. A bust of Gaia holding a scarf under her breasts in Peirce H., and Tyler R., L'art byzantin, II, Paris, 1934, I52 a.

B) Brendel, loc. cit.

2) Gardiner, P., The Coins of the Greek and Scythic Kings of Bactria and India in the British Museum, London, 1886, pl. XXVII, 6. Were it not for the fact that exactly similar half-figures survive as wind gods in Tibctan art, we might be led to believe that these concepts had already become ' secularized ", devoid of their original meaning, and merely decorative (see von Le Coq, fig. 177).

4) These birds may of course be suans which in antique art are the vehicles of the deities of the air. Similar geese or swans appear above the sun chariot on a pillar from Lala Bhagat dedicated to Sürya and the Daun (See $A S I, A R$, $1929-30$, pl. XXXI, d-g, and pp. 132-133).

) Cf. von Le Coq, figs. 223-225. The form of the quadriga motif appears in medieval art in Europe. (Cf. the manuscript portrait of Otto II, Cod. Vat. Lat. 4939 in Brendel, p. 281).

-) For a resumé of this whole subject, see Seyrig, H., Sur quelques sculptures Palmuréniennes: l'attelage deployt, Syria, 1937, XVIII, I, p. so f. 
The two Nike-Athene who appear on the Bāmiyann sun chariot are in type and costume archaisms coming down from the coin types of Menander and Azes: their nearest equivalent in Gandhāra art is the Pallas Athene-Dvārapāla in the museum at Lahore (fig. 9) ${ }^{1}$ ). It seems that, in the fresco, they are possibly intended as portrayals of Bāmyā and Ušāh, the handmaids of dawn who ride with Mithra ${ }^{2}$ ). Their inclusion in the iconography shows distinctly Iranian rather than Indian ideas at work: The sun god and his companions, Danda and Pingala, in the relief stele from Khair Khāna are, in iconography and costume, clearly Indian: they wear the "nordic dress specified for Sūrya in the Matsyapuräna ${ }^{3}$ ). Although bows and arrows are part of the equipment of Uša and Pratyuša, who, in Indian art are the wives of Sūrya, the war-like gear of helmet, lance, and shield brandished by the two attendants at Bāmiyann might suggest Asi, another female guide of Mithra's quadriga, who is described as a noble maiden, invincible in battle ${ }^{4}$ ). Most likely, however, they are intended as the Usasā, of the Sürya iconography in India who here have assumed the accoutrements of the Gandhāra Athene-Dvārapāla type. Except for details such as these, the ideas that colored the Buddha and Maitreya legends really cannot be described as Mithraic rather than Vedic: the features most probably of Western or Mithraic origin are the Sirens, the costumes of the deities, and the four horses of the chariot; in Indian iconography the car of Sürya is described as having one, or an indefinite number of steeds ${ }^{5}$ ).

1) Smith, V. A., History of Fine Art in India and Ceylon, 1930. An interesting Western parallel is seen in a late Roman cameo in which Victories attend the emperor in a quadriga as Kosmokrator (Babelon, E., Catalogue des camées antiques et modernes de la Bibliothèque Nationale, Paris, 1897, 81, XXXVII, 308).

2) Gray, L. H., The foundations of the Iramian religions, F. Cama Or. Inst, n. 15, 1929, p. $164(75), 139(20)$.

i) Hackin, J., Recherches archéologiques au col de Khair khäneh, orés de KËbul, Paris, 1936, p. $22 \mathrm{f}$.

c) Darmesteter, J., The Zend Avesta, 2, S.B.E., XXIII, Yt. XIII, 107; Gray, p. 90; Coomarasuamy, A. K., The darker side of Davn, Washington, 1935, p. 5.

") Herzfeld, Die sasanadischen Quadrigae, p. 131), speaking of the quadriga type, says. Die typen aus Iran, Mittelasien, und Gandhăra wiederspiegeln alle ein graeco-bactrischer frototyp. Den urkundlichen beweis dafür gibt die quadriga sowie im gex'olbe über dem grossen Buddha von Bāmiyan die einige Westlichere und altertümlichere züge aufweist, also die mittelasiatischen und gandhărischen vorkommen :. 
As a study in the merging and survival of the pictorial iconography of religious myths the Bāmiyan fresco is estremely enlightening. We have seen that it marks not only the reception of earlier Vedic or pre-Buddhist concepts into Buddhism in the substitution of the chariot of the Rising Sun for Buddha's Nativity and the Tathāgata himself; there is the further suggestion that Mithraic elements have intruded as well, as is born out by the peculiar resemblance of the whole and of the main figure to Mithraic subjects in Sasanian and Kushan coins and seals. In a wider view this process of assimilation is exactly what took place, as has been illustrated by significant parallels, in medieval European art. Although I do not wish to stress such an influence, in view of the Sasanian style of the vault painting and the Buddhas and donors on the sides, it might not be too much to assume that we have here an indirect derivative from the representations of planetary gods on the famous throne of Kbosrau: certainly it was from that source or, perhaps, from the portrayal of sun and moon gods in Sabaean art that the quadrigae rode into the religious art of the Medieval west. If the Aurae * and the Sirens are indeed borrowings from the pilaff of late classic iconography in Western Asia, they must have been as thoroughly assimilated to the Buddhism of Bāmiyan as the Vedic elements I have mentioned. There is no reason to assume that, in such a complex iconographical conception as this, they are there simply as "decorative and "dead * symbols.

Although I have spoken of "influences in this painting at Bāmiyān I do not wish to imply that influences - in the sense of imported ready-made motifs - determined the form that it has. Obviously the form was determined by the religious ideas it was meant to express. Such features as are recognizably Western Asiatic or Iranian in origin entered the religion of the Bāmiyan region as ideas and then later came to be portrayed in painting. In no sense have I meant to imply that the religion or the meaning of the religious imagery was in any way influenced by any pre-existing icon: the idea of Sirens as attendants on the planets entered the region from the West and becomes incorporated syncretically into the Sūrya iconography; the concept of the wives of the Sun is Indian in origin but is explained pictorially in a style mainly Sasanian and Late Antique in origin. The style of the whole composition is naturally determined by the race of the particular artists who executed it. 
It would be anachronistic to suppose that the followers of the Eastern religions did or were expected to concern themselves with the processes that interest us as revealing trends in the development of religion and iconography. Probably it was considered enough that some could recognize the very simplest interpretation of Surrya as attendant; others, perhaps, Mithra in the host of Buddha's emanations. In the twelfth century probably not one worshipper in a hundred who stood before the portal of the Doom at Autun understood its deeper mysteries, nor did the pilgrim in the cathedral at Chartres understand - or need to understand - the processes that had installed Mary the Mother-Goddess there as Queen of Heaven. The mass of visitors came to pray and, as Suger said, to be raised by the material to the immaterial: the particular shape of the form or diagram of god mattered very little. In both these cases of syncretism the worshippers went away satisfied with the simplest interpretation.

BENJAMIN ROWLAND, JR. 
jamin Rowland, Jro - Buddha and the sun god

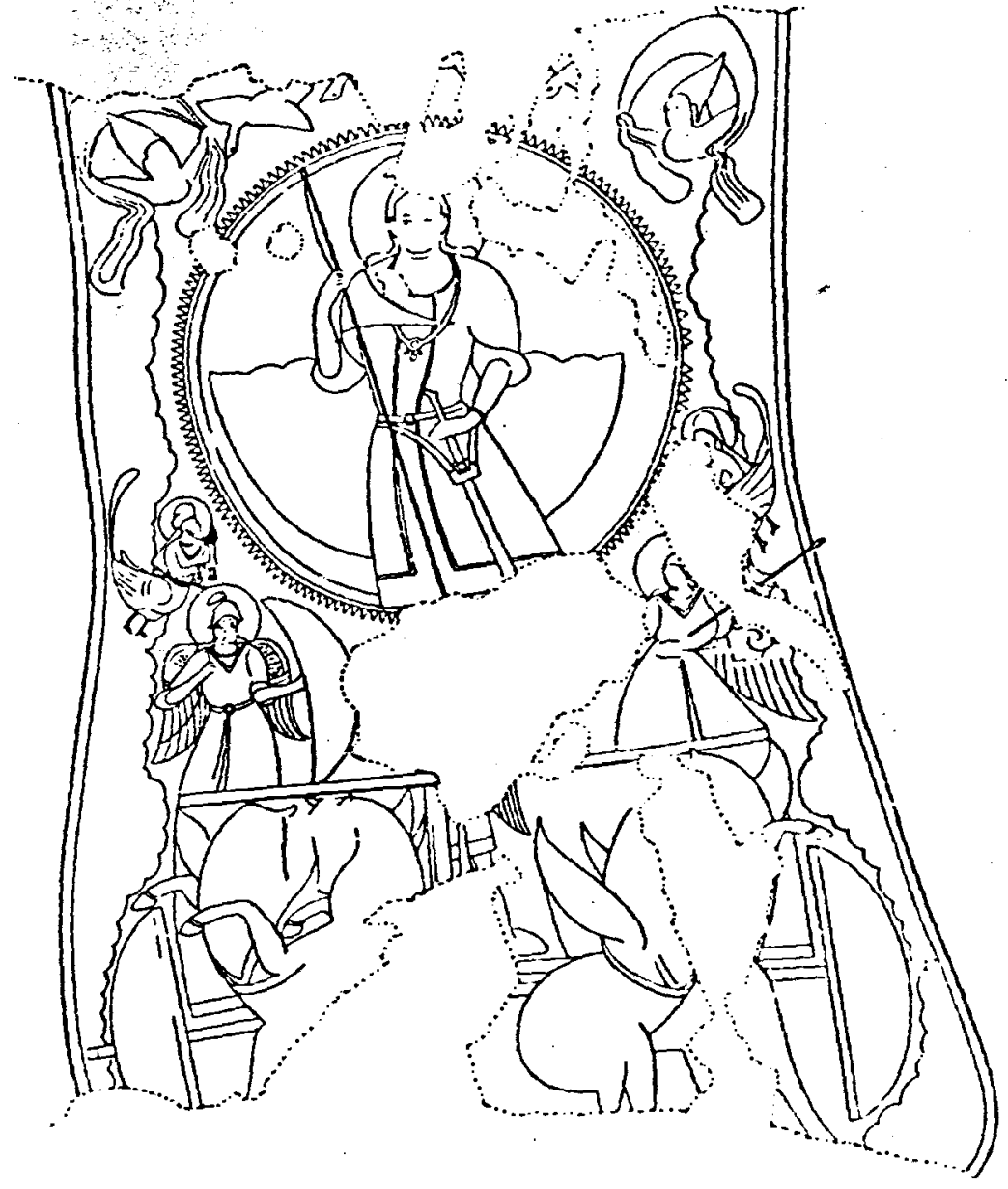

Fig. 1. - Sun God, Niche of the 120 font Buddha, Bamisan. 